\title{
DAMPAK DAN STRATEGI UNTUK MENGATASI KECEMASAN BERBICARA DALAM PEMBELAJARAN BAHASA INGGRIS SEBAGAI BAHASA KE-2 (ESL) DAN ASING (EFL)
}

\author{
THOMAS JOKO PRIYO SEMBODO, S.S., M.A. \\ Program Studi Sastra Inggris Fakultas Ilmu Budaya Universitas Gadjah Mada \\ thomassembodo@ugm.ac.id
}

\begin{abstract}
This paper aims at addressing the issue of speaking anxiety in ESL/EFL learning. This study of literature is believed to be significant as it can give insights into ESL/EFL anxiety and how it can be coped. In doing so, this paper starts with the description of the nature of language anxiety in ESL/EFL learning particularly speaking anxiety, its theoretical overview, causes of such an anxiety, and its effects on ESL/EFL learning. Furthermore, there is a review of studies on strategies used to cope with language and speaking anxiety in ESL/EFL learning or classrooms. These coping strategies can be classified into two categories, namely 1 ) self-employed strategies employed by anxious learners consisting of five strategies-in which two are inapplicable, and 2) employed by teachers, which consists of three strategies. Those strategies are able to help overcome the learner's anxiety, leading to the more successful ESL/EFL learning. In addition, in ESL/EFL classrooms teachers play a key role in relieving anxiety experienced by their students. In conclusion, speaking anxiety can have debilitating impacts on learners experiencing it. However, this problem can be overcome with strategies employed by learners and their teachers.
\end{abstract}

Keywords: speaking anxiety, debilitating impacts, ESL/EFL learning, ESL/EFL teachers, coping strategies

Intisari

Makalah ini bertujuan untuk menjelaskan dan memberikan solusi untuk mengatasi masalah kecemasan berbicara dalam pembelajaran ESL/EFL (bahasa Inggris sebagai bahasa ke dua atau bahasa asing). Penelitian ini dimulai dengan mendeskripsikan sifat kecemasan bahasa dalam pembelajaran ESL/EFL terutama kecemasan berbicara, kemudian memberikan paparan teoritis, penyebab kecemasan berbicara, dan pengaruhnya terhadap proses pembelajaran. Selanjutnya, dipaparkan kajian tentang strategi yang digunakan untuk mengatasi kecemasan bahasa terutama kecemasan berbicara. Hasil analisis menunjukkan dua kategori strategi. Terdapat lima strategi yang digunakan oleh para pembelajar yang mengalami kecemasan namun hanya tiga yang bisa diterapkan. Sedangkan strategi yang digunakan oleh pengajar terdapat tiga strategi. Dengan penerapan strategi tersebut, pembelajar mampu mengatasi kecemasan dan dapat belajar ESL/EFL dengan baik. Selain itu, di kelas-kelas ESL/EFL, para pengajar memainkan peran kunci dalam mengurangi kecemasan yang dialami oleh murid. Sebagai kesimpulan, kecemasan berbicara bisa memberi dampak buruk pada pembelajar ESL/EFL. Akan tetapi, masalah ini dapat diatasi dengan strategi yang digunakan sendiri oleh para pembelajar ESL/EFL dan guru mereka.

Kata kunci: kecemasan berbicara, dampak buruk, pembelajaran ESL/EFL, guru ESL/EFL, strategi mengatasi kecemasan 


\section{Pendahuluan}

Para ahli bahasa sejak lama tertarik dengan kecemasan dalam pembelajaran bahasa kedua atau asing karena efeknya yang melemahkan para pembelajar dan proses pembelajarannya. Ketertarikan ini dimulai pada pertengahan tahun enam puluhan dengan kecurigaan para peneliti bahwa pembelajaran bahasa ke dua atau asing dapat dihambat oleh kecemasan yang dialami oleh peserta didik (Ewald, 2007). Berkaitan dengan fakta ini, banyak periset pada beberapa dekade selanjutnya, seperti yang telah digarisbawahi Horwitz dan MacIntyre bahwa kecemasan di dalam kelas bahasa kedua atau asing berdampak negatif (dalam Ewald, 2007). Salah satu argumen mengapa kecemasan cenderung terjadi di dalam kelas bahasa ke dua atau asing dikemukakan oleh Guiora yang menegaskan bahwa pembelajaran bahasa adalah "persoalan psikologis yang sangat meresahkan" karena secara langsung mengancam konsep diri dan pandangan dunia dari seseorang (dalam Horwitz, Horwitz, \& Cope 1986, hal. 125).

Dalam upaya untuk lebih menguraikan masalah ini, MacIntyre dan Gardner berpendapat bahwa kecemasan bahasa sebenarnya adalah salah satu bentuk kecemasan sosial karena hal ini terutama disebabkan oleh fitur tau ciri-ciri komunikasi dan sosial dari pembelajaran bahasa (dalam Maclntyre, 1995). Oleh karena itu, gejala umumnya adalah bahwa kecemasan mungkin muncul sebagai perasaan tegang dan ketidaknyamanan (afektif), evaluasi diri yang negatif (kognitif), dan kecenderungan untuk menarik diri karena ada kehadiran orang lain (perilaku) (Schwarzer dalam Maclntyre, 1995; Sarason \& Spielberger dalam Maclntyre 1995).

Ganschow dan Sparks (2007) menegaskan bahwa manifestasi kecemasan dalam situasi pembelajaran bahasa ke dua atau asing yang ditunjukkan oleh peserta didik dapat diklasifikasikan sebagai reaksi kecemasan spesifik yang serupa dengan kecemasan terhadap matematika atau fisika. Horwitz, Horwitz, \& Cope (1986) mendukung pernyataan ini dengan mengemukakan bahwa perasaan subyek, indikasi psiko-fisiologis, dan reaksi perilaku mereka dalam situasi pembelajaran bahasa pada dasarnya sama dengan kecemasan spesifik lainnya. Umumnya, istilah kecemasan khusus digunakan oleh psikolog untuk membuat 
perbedaan antara orang-orang yang biasanya cemas dalam berbagai konteks sosial dan mereka yang hanya cemas hanya dalam situasi tertentu (Ganschow \& Sparks, 2007). Dalam kasus situasi pembelajaran bahasa Inggris, peserta didik yang mengalami kecemasan dapat menjadi anggota kelompok pertama atau ke dua yang dinyatakan oleh Ganschow \& Sparks. Karena kedua jenis pembelajar mengalami jenis kecemasan yang sama, yaitu kecemasan bahasa, dan biasanya menunjukkan gejala yang sama dalam aktivitas belajar mereka, mereka termasuk dalam satu kategori yang merupakan peserta didik yang cemas.

Peserta didik yang cemas umumnya menunjukkan indikasi yang sama. Dalam beberapa penelitian, hasil menunjukkan bahwa pembelajar bahasa ke dua atau asing yang paling cemas mengalami kekhawatiran, ketakutan, dan bahkan ketakutan di kelas (Horwitz, Horwitz, \& Cope, 1986). Mereka lebih jauh menunjukkan bahwa dalam terlibat dengan kegiatan belajar, pelajar ini juga dapat mengalami kesulitan dalam berkonsentrasi, tidak sadar, berkeringat, dan mengalami detak jantung yang meningkat dan tidak teratur. Sejalan dengan hal ini, Daubney (n.d.) mengemukakan bahwa reaksi fisik yang ditunjukkan oleh peserta didik yang cemas dihasilkan dari energi negatif (kegelisahan) yang secara khusus memengaruhi ingatan jangka pendek peserta didik. Sebagai dampak utama dari kecemasan seperti itu, Horwitz, Horwitz, \& Cope (1986) mengklaim bahwa pelajar yang cemas ini akan menunjukkan perilaku melarikan diri seperti melewatkan kelas atau menunda pekerjaan rumah.

Sehubungan dengan masalah yang ada yang disorot dalam makalah ini, kecemasan dalam bahasa ke dua atau asing, dan fakta bahwa ada strategi yang diajukan untuk mencegah atau meringankannya (Kondo \& Ling, 2004; Ewald, 2007), makalah ini bertujuan untuk mengemukakan beberapa strategi yang berguna dan bisa diterapkan. Selanjutnya, makalah ini menjelaskan secara komprehensif strategi dari sudut pandang guru dan pelajar. Gregersen dan Horwitz (2002) mendukung anggapan bahwa kecemasan bahasa ke dua atau asing cenderung terkait dengan penangkapan komunikasi yang merupakan salah satu kegelisahan yang dialami dalam kehidupan sehari-hari di mana L1 diucapkan. Gagasan ini 
nampaknya sejalan dengan fakta bahwa kesadaran akan kecemasan tentang berbicara dengan bahasa Inggris semakin banyak dan diperhatikan oleh peneliti. Untuk alasan ini, makalah ini berusaha untuk menjelaskan dasar dari kecemasan berbahasa Inggris dan khususnya bagaimana mengatasi hal tersebut dapat menguntungkan bagi kinerja dan akuisisi pelajar EFL.

\section{Metodologi Penelitian}

Studi ini merupakan tinjauan pustaka, dan oleh karena itu kajian ekstensif dari sumber primer adalah satusatunya metodologi. Sumber utama ini meliputi buku, artikel, studi dan/atau diskusi kritis di bidang bahasa Inggris sebagai bahasa ke dua (ESL) dan asing (EFL), khususnya kecemasan berbicara dalam pembelajaran ESL/EFL. Informasi dan bukti yang ditemukan dalam sumbersumber ini digunakan untuk mendukung argumen penulis yang terkait dengan isu kecemasan berbicara dalam konteks ESL/EFL. Dengan membentuk argumen dan menarik kesimpulan berdasarkan bukti dan informasi yang ada, masalah penelitian yang diangkat dalam makalah ini dapat dipaparkan dan dicarikan solusinya secara menyeluruh.
Secara teknis, langkah pertama yang dilakukan peneliti adalah mencari sumber-sumber literatur yang tidak hanya relevan namun juga yang secara akademik dapat dianggap sebagai sumber-sumber kuat yang dapat diacu. Para penulis sumber-sumber tersebut adalah para praktisi dan ahli di bidang pembelajaran ESL/EFL terutama yang terkait dengan kecemasan berbicara dalam pembelajaran ESL/EFL.

Langkah ke dua yang dilakukan adalah membaca sumber-sumber tersebut secara mendalam, obyektif, dan kritis untuk menemukan ide-ide pokok dari argumen yang dipaparkan di masingmasing sumber. Ide-ide pokok tersebut kemudian dibandingkan untuk menemukan keterkaitan, persamaan, serta perbedaannya. Setelah itu, peneliti mulai menyusun deskripsi dan argumennya di dalam artikel studi literatur ini.

\section{Hasil dan Pembahasan}

Dalam situasi pembelajaran EFL, terutama dalam aktivitas berbicara, interaksi sosial yang membangkitkan kegelisahan dapat digambarkan melalui situasi ketika sekelompok pelajar sedang mempelajari bahasa ke dua atau bahasa 
asing di kelas. Dalam situasi belajar ini, interaksi sosial mungkin sering dilibatkan dalam kendali guru meskipun sebagian besar kegiatannya bukanlah komunikasi dalam arti sebenarnya. Bagaimanapun, imitasi interaksi sosial ini mengharuskan pelajar menggunakan bahasa fungsional (dimaksudkan untuk tujuan tertentu) karena di luar kelas mereka berinteraksi dengan berbagai macam orang dalam konteks aktual, yang dirancang untuk tujuan tertentu. Dengan cara ini, pelajar dihadapkan pada fungsi aktual dari interaksi sosial dan komunikasi. Karena keduanya terbuka dan diharuskan untuk terlibat dalam interaksi sosial yang dibangun dengan menggunakan bahasa yang bukan bahasa ibu mereka, beberapa pelajar mungkin mengalami kecemasan yang dapat mengganggu interaksi mereka yang pada gilirannya berdampak negatif terhadap pembelajaran, kinerja, dan akhirnya akuisisi mereka.

Pappamihiel (2002) mengklaim bahwa belum banyak penelitian yang dilakukan mengenai dampak kecemasan bahasa ke dua atau asing terhadap perolehan nilai bahasa Inggris di kalangan pelajar EFL/ESL. Bagaimanapun, hasil dari kecemasan seperti itu yang dialami dan ditunjukkan oleh pelajar bahasa Inggris telah membawa beberapa peneliti ke sebuah pernyataan tegas bahwa kecemasan bahasa ke dua atau asing dapat memiliki efek merugikan terhadap pembelajaran bahasa Inggris (Pappamihiel, 2002). Beberapa peneliti berpendapat bahwa kecemasan bahasa ke dua atau asing dapat secara signifikan dan negatif memengaruhi pelajar bahasa Inggris dalam belajar berbicara secara khusus. Dalam studi mereka, Horwitz, Horwitz, \& Cope (1986) menemukan bahwa utamanya, siswa mengalami kecemasan saat mereka ditugaskan untuk melakukan tugas yang berkaitan dengan dua dari empat keterampilan makro yaitu mendengarkan dan berbicara. Mereka terus menegaskan bahwa pelajar bahasa ke dua atau asing lebih cenderung mencari bantuan dari orang lain selain guru mereka seperti di pusat belajar siswa ketika mereka memiliki masalah dengan tugas berbicara mereka. Dengan mendukung pernyataan ini, Woodrow (2006) menemukan bahwa berkomunikasi dengan penutur asli di setting L2 adalah penyebab stres bagi pelajar ESL/EFL. Temuan Woodrow adalah bukti kuat bagaimana berhadapan dengan komunikasi bahasa Inggris lisan adalah situasi yang mengancam. Selain 
itu, kecemasan juga telah ditemukan pada pembelajaran keterampilan makro lainnya. Ewald (2007) berpendapat bahwa kecemasan menulis bahasa ke dua atau bahasa asing dan kecemasan kelas bahasa ke dua atau asing saling terkait meskipun faktanya mereka sebenarnya asalah konsep otonom. Dia menyiratkan bahwa pelajar juga bisa cemas dalam mempelajari keterampilan menulis. Dalam studi lain, Pappamihiel (2002) mengungkapkan bahwa pelajar yang merasa kemampuan membaca dan menulisnya bagus kurang merasa cemas daripada mereka yang percaya bahwa kemampuan membaca dan menulis mereka buruk.

Dalam proses pembelajaran, siswa EFL/ESL yang cemas cenderung menunjukkan keengganan untuk menghasilkan perkataan atau kalimat yang kompleks dalam kegiatan berbicara. Horwitz, Horwitz, \& Cope (1986) mengemukakan bahwa siswa ESL/EFL yang cemas cenderung menghindari mengungkapkan informasi dalam kalimat yang kompleks dan panjang karena mereka mungkin akan merasa cemas. Chang dan Chen (2004) menunjukkan bahwa kecemasan negatif bahasa ke dua atau asing memiliki pengaruh kausal terhadap persepsi bahwa kelas bahasa ke dua atau asing itu sulit, kesulitan dalam belajar di kelas, skor rendah, dan kurangnya keterampilan untuk berkembang. Dapat disimpulkan bahwa pelajar yang cemas cenderung menganggap bahwa bahasa belajar selalu sulit dilakukan sehingga mereka selalu merasa minder saat belajar bahasa ke dua atau bahasa asing. Asumsi ini yang sebagian dipengaruhi oleh sejarah frustrasi pembelajaran bahasa mereka (Chang dan Chen 2004) pada gilirannya akan membuat pelajar kesulitan dalam mempelajari bahasa (menerima dan memahami masukan). Karena pemahaman mereka yang buruk, pembelajaran mereka tampaknya menjadi tidak berhasil yang tercermin dalam nilai mereka yang rendah. Terlepas dari kemungkinan bahwa kecemasan dalam ujian juga akan berkontribusi saat mereka duduk dalam ujian, nilai rendah mereka menunjukkan bahwa materi yang dipelajari sepertinya tidak terserap dan dicerna. Pada akhirnya, karena pembelajaran tidak benar-benar terjadi, kemampuan bahasa mereka tidak akan berkembang secara signifikan.

Pembelajaran yang tidak berhasil ini sangat mungkin berdampak pada 
performa siswa dalam berbicara. mereka proses dalam mempelajari Daubney (n.d.) menjelaskan bahwa kecemasan bahasa ke dua atau asing akan mengganggu ingatan jangka pendek pelajar yang mencegah pelajar untuk merumuskan kata dan pemikiran dalam waktu yang cukup yang diperlukan untuk mengubahnya menjadi kalimat verbal dan komunikatif. Lebih buruk lagi, pelajar terkadang bisa kehilangan kata-kata (membeku) dan akhirnya produktivitas bahasa ke dua atau bahasa asing mereka akan berkurang. Dapat dikatakan bahwa pelajar ESL/EFL yang cemas cenderung menunjukkan kinerja buruk karena kecemasan mereka mencegah mereka untuk menunjukkan kemampuan berbicara mereka secara optimal. Seperti telah disebutkan di atas bahwa menghasilkan kalimat sederhana yang terstruktur dalam mengkomunikasikan gagasan dianggap kurang membuat frustrasi dan karena itu pelajar sangat mungkin merasa lebih aman dari kecemasan yang tinggi. Dalam hal performa berbicara, kalimat yang sederhana ini terlihat kurang adanya penguasaan syntax dan grammar. Dengan keterbatasan tersebut, pelajar cenderung menghasilkan pengetahuan yang lebih sedikit daripada pengetahuan yang bahasa (Mclntyre \& Gardner, 1994, hal. 301 dalam Ganschow \& Sparks, 2007). Selain itu, Horwitz, Horwitz, \& Cope (1986) berpendapat bahwa kecemasan bahasa ke dua atau asing menghalangi pelajar dalam melakukan kefasihan dalam bahasa ke dua atau asing yang telah mereka pelajari dan kuasai.

Dari sisi perolehan, Krashen (dalam Horwitz, Horwitz, \& Cope, 1986) berpendapat bahwa kemampuan menyerap bahan yang dipelajari dalam bahasa target akan terhambat. Oleh karena itu, perolehan bahasa ke dua di antara pelajarnya akan stagnan saat kecemasan mereka memainkan peran dalam munculnya filter afektif yang menyebabkan pelajar tidak berhasil menerima masukan bahasa. Argumen Krashen secara tidak langsung menghubungkan kecemasan bahasa ke dua atau asing dengan perolehan bahasa ke dua, proses belajarnya, dan bagaimana hal itu dilakukan oleh pelajar. Ketika seorang pelajar ESL/EFL mengalami kecemasan di kelas, Krashen menegaskan bahwa dia tidak akan menerima masukan bahasa yang dia pelajari karena filter afektif mencegahnya untuk menjadi seperti itu. Dengan cara ini, masukan 
bahasa ini tidak akan diserap dan dipahami oleh pelajar karena ia menganggap masukan itu sulit dan membuat frustrasi. Dengan kata lain, kemampuan kognitifnya dalam situasi ini tidak dapat dimanfaatkan dan oleh karena itu proses pembelajaran tidak berlangsung. Akibatnya, karena mempraktikkan bahasa yang dipelajari membutuhkan penguasaan masukan bahasa yang seharusnya terjadi dalam proses pembelajaran, pelajar sangat mungkin memberikan performa yang buruk. Pada akhirnya, kemampuan bahasa pelajar kemungkinan besar tidak berkembang. Secara keseluruhan, telah terungkap bahwa kecemasan bahasa ke dua atau asing dialami oleh pelajar yang cemas dalam tiga tahap pembelajaran; masukan, proses, dan keluaran (Bailey, Onwuegbuzie, dan Daley 2000).

\section{Strategi yang Dilakukan Sendiri oleh} Murid

Menanggapi masalah berat dalam pembelajaran ESL/EFL ini, banyak penelitian telah dilakukan untuk merumuskan strategi baik bagi pelajar maupun guru. Di antara peneliti lain, Kondo dan Ling (2004), dalam penelitian mereka, berhasil mengidentifikasi lima strategi yang biasanya dilakukan oleh pelajar EFL dalam mengatasi kecemasan mereka. Mereka adalah persiapan, relaksasi, berpikir positif, mencari teman, dan mengundurkan diri. Strategi ini berlaku umum untuk pelajar EFL; namun, dasar dari strategi ini memungkinkan mereka diterapkan di kelas ESL/EFL dan kelas berbicara. Masing-masing strategi diuraikan dalam pembahasan berikut.

Strategi pertama adalah persiapan, yang biasanya dilakukan oleh pelajar untuk mencoba mengurangi efek kecemasan, terutama dengan memperbaiki strategi belajar mereka selama di kelas serta studi mandiri di luar kelas secara individu atau berkelompok. Ini bisa mencakup memberi lebih banyak waktu dan energi untuk meninjau ulang materi di rumah dan berusaha meringkas kuliah dengan lebih baik. Berkenaan dengan kelas berbicara, persiapan dapat berbentuk seperti mempraktikkan materi yang telah dipelajari sebelumnya dengan teman sebaya di luar kelas dan mendiskusikannya. Contoh lain adalah merencanakan terlebih dahulu untuk kegiatan selanjutnya terutama saat aktivitas membutuhkan performa individual seperti presentasi kelompok atau individu. Dalam hal ini, seorang 
pelajar dapat menyiapkan garis besar untuk memandu presentasinya dan berdiskusi dengan teman sebaya atau orang-orang yang dapat membantu seperti orang tua atau konselor di pusat belajar siswa. Persiapan ini bisa mencakup latihan tapi tidak menghafal dan/atau mempraktikkan pengucapan kata-kata sulit. Selain persiapan 'akademis', bermanfaat juga bagi pelajar untuk cukup beristirahat dan makan dengan baik sebelum hari presentasi. Dengan menggunakan strategi persiapan ini, pelajar diharapkan lebih yakin bahwa dia telah menguasai materi dan bagaimana dia akan membicarakannya di depan teman dan guru mereka. Persepsi diri subyektif ini diyakini dapat mengurangi tingkat kecemasan dalam aktivitas berbicara.

Kedua, pelajar harus mencoba untuk bersantai saat berada di kelas. Tujuan dari strategi ini adalah untuk meminimalkan atau mengurangi rasa gugup dan ketakutan saat pelajar menghadapi situasi kelas bahasa. Teknik yang umum untuk santai adalah dengan hanya mengambil satu atau dua napas dalamdalam sehingga bisa membantu melakukan teknik berikutnya yaitu mencoba untuk tidak panik dan tetap tenang. Dengan demikian, pelajar diharapkan dapat tampil maksimal sehingga bisa memanfaatkan segala hal yang telah mereka siapkan terlebih dahulu. Dengan bersikap santai, pelajar lebih mungkin untuk bisa menggunakan kognisi mereka dan dengan demikian kinerjanya akan lebih terkelola dan terstruktur. Selain itu, ketika pelajar merasa santai, mereka akan lebih baik dalam mengendalikan suara, artikulasi, dan ucapan mereka yang pada akhirnya berkontribusi pada penampilan mereka.

Strategi selanjutnya adalah berpikir positif. Kondo dan Ling (2004, hal. 262) berpendapat bahwa strategi ini memiliki "fungsi paliatif dalam menekan proses kognitif bermasalah yang mendasari kecemasan siswa." Menurut kedua peneliti ini, strategi ini bisa mencakup persepsi diri bahwa seseorang dapat berkinerja baik atau mencoba menikmati ketegangan situasi belajar. Dalam situasi pembelajaran berbicara, pemikiran positif ini sangat mungkin terjadi ketika seorang pelajar telah membuat persiapan yang baik dan santai. Persepsi bahwa segala sesuatu akan berjalan dengan baik dan lancar didukung oleh kedua fakta ini. Oleh karena itu, ketika seorang pelajar percaya bahwa presentasinya akan dilakukan 
dengan baik, dia akan merujuk kembali pada apa yang telah dia lakukan sebelumnya dan menyadari bahwa dia tidak perlu panik. Dengan cara ini, berpikir positif malah akan meningkatkan rasa percaya dirinya. Akhirnya, dia akan mendapatkan lebih banyak kendali atas emosinya dan kemampuan kognitifnya dan dengan begitu kecemasannya kemungkinan besar akan berkurang.

Sejauh ini, strategi yang dijelaskan di atas tampaknya bermanfaat bagi pelajar bahasa Inggris. Namun, tidak semua dari lima strategi yang diidentifikasi oleh Kondo dan Ling dapat direkomendasikan dan dianjurkan secara tepat pada pelajar. Pengunduran diri, misalnya, inilah strategi keempat yang terjadi ketika seorang pelajar yang cemas memutuskan untuk melepaskan diri dari tantangan (tugas atau kewajiban) dengan menyerah atau tidur selama kelas atau bahkan melewatkannya. Meskipun kedua peneliti berpendapat bahwa strategi ini bekerja untuk beberapa siswa dalam meminimalkan dampak kecemasan mereka, ini jelas bukan strategi produktif. Strategi lain yang cenderung didorong dalam pembelajaran bahasa Inggris adalah mencari teman. Ini mengacu pada kemauan seorang pelajar yang cemas untuk mencari pelajar lain yang memiliki masalah yang sama dalam memahami penjelasan guru dan/atau mengalami kecemasan di kelas. Kedua peneliti tersebut berpendapat bahwa strategi ini dapat mengurangi kecemasan dari pelajar yang cemas karena menyadari bahwa ada pelajar lain yang memiliki kesulitan serupa dapat berfungsi sebagai "regulasi emosional dengan perbandingan sosial" (Kondo \& Ling, 2004, hal. 262). Namun, dengan hanya atau terlalu banyak mengandalkan strategi ini mungkin membuat pelajar menjadi 'kecanduan' terhadap perasaan lega seperti itu, tanpa mempertimbangkan apa yang harus mereka lakukan untuk mengatasi kecemasan mereka. Dengan kata lain, melakukan pencarian teman yang lebih banyak tanpa melakukan persiapan yang baik, mencoba untuk rileks, dan berpikir positif tidak akan membantu kinerja pelajar. Oleh karena itu, kegelisahan mereka sepertinya hanya akan berkurang sementara karena di saat mereka harus melakukan performa dan menyadari bahwa mereka tidak siap, kecemasan mereka akan meningkat seketika. 


\section{Strategi Guru}

Dari sudut pandang guru, peran mereka adalah kunci untuk mengatasi kecemasan yang dialami oleh siswa mereka. Seorang guru adalah koordinator kelas dan pengatur dalam kegiatan belajar. Apapun yang terjadi di kelas diputuskan oleh guru. Sebagai fasilitator, guru harus memiliki kepekaan untuk memahami kondisi muridnya termasuk melihat potensi masalah seperti kecemasan di kalangan siswanya. Oleh karena itu, seorang guru harus tahu apa yang terbaik yang akan diterapkan pada murid-muridnya termasuk strategi untuk mengurangi kecemasan bahasa ke dua atau bahasa asing terutama kecemasan berbicara.

Seperti yang disarankan oleh Ganschow dan Sparks (dalam Chang dan Cheng, 2004), strategi guru yang baik dalam membantu pelajar untuk mengatasi kecemasan mereka adalah menyesuaikan gaya mengajar mereka di kelas. Penyesuaian ini bertujuan untuk mengakomodasi kesulitan belajar yang mungkin dialami oleh pelajar. Dalam menggunakan strategi ini, seorang guru dapat mengurangi kecepatan mengajarnya, menggabungkan presentasi visual dan pendengaran, dan memberikan instruksi elemen bahasa secara langsung. Di kelas berbicara, sangat mungkin jika seorang guru memperlambat laju bicaranya saat menjelaskan atau memberikan arahan, ini akan sangat bermanfaat bagi siswa. Dengan demikian, guru lebih cenderung mengurangi atau mencegah kesulitan pelajar dalam memahami pelajarannya sehingga mereka akan merasa lebih mudah untuk memahami makna yang sedang diajarkan oleh guru mereka. Ketika para siswa percaya bahwa mereka mengerti sebagian besar apa yang guru mereka jelaskan, mereka akan merasa nyaman mendengarkan dan karena itu mereka akan kurang cemas. Akhirnya, siswa akan lebih cenderung menjawab pertanyaan, dengan percaya diri melakukan percakapan berpasangan, atau berbagi dalam kelompok karena mereka yakin mereka tahu apa yang harus dilakukan. Dalam kasus lain, ketika sekelompok pelajar memerhatikan guru mereka dengan menggunakan gambar atau tampilan PowerPoint, mereka akan lebih menikmati presentasi ini. Selain itu, gambar yang digunakan oleh guru akan berfungsi sebagai isyarat bagi pelajar mengenai gagasan apa yang ingin disampaikan oleh guru mereka. Hasilnya, 
pelajar akan mengalami lebih sedikit kesulitan belajar sehingga mereka cenderung tidak cemas.

Strategi lain diajukan oleh Woodrow (2006) yang menemukan bahwa kecemasan berbicara bahasa ke dua atau bahasa asing mungkin karena kurangnya keterampilan pelajar. Dalam hal ini, dia mengusulkan agar seorang guru memerhatikan lebih dekat perkembangan keterampilan siswa dengan menyediakan berbagai sumber bahasa Inggris sehari-hari yang nyata bagi murid-muridnya baik di dalam maupun di luar kelas. Dia kemudian memberikan contoh dari model tugas yang bisa mendorong pembelajaran semacam itu. Tugas ini bisa disebut tugas di luar kelas yang bertujuan untuk mengekspos dan melibatkan pelajar dalam komunikasi dunia nyata dalam setting sebenarnya. Dengan terlebih dahulu menetapkan link ke beberapa institusi seperti perpustakaan setempat, komunitas informal di luar kampus, atau beberapa klub mahasiswa, seorang guru dapat meminta atau mendorong muridmuridnya untuk masuk ke salah satu 'setting' ini dan mereka kemudian dapat diminta untuk membagikan pengalamannya dengan kelas atau menulis laporan kelompok dan menempatkannya di buletin kelas. Dengan terlibat dengan komunitas ini, pelajar diharapkan untuk menggunakan materi yang dipelajari di kelas dalam situasi nyata dan karenanya mereka dapat terus meningkatkan kemampuan komunikasi mereka. Ini akan berkontribusi pada peningkatan kemampuan berbicara yang dirasakan pelajar sehingga mereka lebih percaya diri untuk berpartisipasi dalam kelas berbicara dan pada akhirnya mereka dapat mengatasi kecemasan mereka.

Strategi terakhir yang diajukan adalah bahwa seorang guru harus menciptakan suasana yang nyaman dan bersahabat sehingga dapat mencegah atau setidaknya mengurangi kecemasan yang dialami muridmuridnya (Dornyei, 2001, hal. 40). Setidaknya ada tiga kemungkinan alternatif dalam menciptakan suasana yang baik dalam pembelajaran ESL/EFL terutama di kelas berbicara. Pertama, Brophy, Casado, dan Derechiwski; Gregersen dan Horwitz menyarankan agar seorang guru dapat menciptakan lingkungan belajar yang ramah dan mendukung (dalam Ewald, 2007). Ini bisa termasuk pembentukan hubungan seperti teman (hubungan baik) antara guru dan muridnya. Dia harus menempatkan dirinya tidak sebagai orang yang tahu segalanya atau sebagai orang yang paling cerdas di kelas, 
sebaliknya, dia harus memosisikan dirinya sebagai mitra pembelajaran yang akan berbagi, mengerti, dan membantu siswa. Dengan demikian, tidak akan ada jarak sosial antara guru dan siswa. Murid-muridnya akan cenderung merasa bebas dalam berinteraksi dengan guru mereka dan juga mengambil risiko dalam melakukan tugas atau aktivitas (Nunan, 1999, hal. 235). Hasilnya, para siswa akan merasa nyaman dalam menghadapi masalah belajar mereka, dan dalam situasi ini, kecemasan cenderung tidak terjadi. Cara lain dalam menyiapkan atmosfir pembelajaran yang baik adalah dengan memberikan pemahaman bahwa kesalahan merupakan bagian normal dari proses pembelajaran (Dornyei, 2001, hal. 42). Meskipun kebanyakan orang sadar bahwa ada orang yang membuat kesalahan dalam proses belajar termasuk dalam pembelajaran bahasa, banyak pembelajar ESL/EFL takut melakukan kesalahan sehingga menimbulkan kecemasan di dalamnya. Untuk alasan ini, seorang guru bahasa Inggris harus bisa membuat muridnya percaya bahwa membuat kesalahan bukanlah dosa. Karena ketika para siswa takut melakukan kesalahan, mereka akan enggan berbicara di kelas dan jika mereka enggan berbicara, itu berarti mereka kurang berlatih dan tidak belajar, yang pada akhirnya menyebabkan kinerja buruk. Keengganan mereka mungkin terkait dengan kekhawatiran mereka terhadap persepsi pelajar lainnya atau bahkan guru mereka.
Oleh karena itu, guru juga harus membuat muridnya mengerti bahwa menertawakan atau mengkritik orang lain yang melakukan kesalahan bukanlah sikap yang baik. Bagi guru itu sendiri, dia harus menindaklanjuti strategi ini dengan memberi umpan balik positif saat muridnya mengambil risiko dan membuat kesalahan (Nunan, 1999, hal. 235). Terakhir, cara untuk membuat suasana yang kondusif bagi pembelajaran ESL/EFL adalah memanfaatkan kerja kelompok. Ewald (2007) mengemukakan bahwa untuk mencegah atau setidaknya mengurangi kecemasan pelajar, beberapa prosedur praktis dapat dimasukkan ke dalam pendekatan pengajaran. Sebagai contoh, dalam pengajaran bahasa komunikatif, guru menggunakan kerja kelompok untuk memungkinkan siswa berinteraksi dengan pasangan mereka secara bebas sehingga mereka merasa lebih nyaman di kelas.

\section{Kesimpulan}

Makalah ini memaparkan serta mendiskusikan sifat kecemasan bahasa dalam pembelajaran ESL/EFL khususnya kecemasan berbicara. Gambaran teoretis, penyebab kecemasan bahasa dan dampaknya terhadap pembelajaran ESL/EFL telah dijelaskan.

Selain itu, makalah ini juga menjelaskan beberapa efek atau manifestasi dari kecemasan seperti yang 
ditunjukkan oleh pelajar yang cemas. Yang terpenting, strategi dari sudut pandang pelajar dan guru dalam mengatasi kecemasan telah diuraikan. Strategi ini dengan jelas menunjukkan bahwa pelajar yang cemas dapat dibantu dan didorong untuk mengatasi kecemasan mereka sehingga dapat belajar dengan sukses, berkinerja lebih baik, dan akhirnya memeroleh bahasa secara efektif.

Ada tiga strategi yang dapat dilakukan sendiri oleh murid yang diusulkan dalam makalah ini; persiapan, relaksasi, dan pemikiran positif. Namun, ada dua strategi yang tampaknya kontraproduktif dan oleh karena itu diyakini tidak dapat diterapkan (pencarian kawan dan pengunduran diri).

Dari sudut pandang guru, ada tiga strategi yang harus dilakukan (menyesuaikan gaya mengajar, lebih memerhatikan perkembangan keterampilan siswa, dan menciptakan suasana belajar yang kondusif). Terakhir, peran guru dalam mengurangi kecemasan pada para siswa mereka sangat penting karena mereka memiliki kendali atas manajemen serta peraturan kelas. Seorang guru dapat dianalogikan sebagai seorang nakhoda kapal yang mempunyai kekuasaan untuk mengambil keputusan seberapa cepat sebuah kapal berlayar, ke arah mana kapal itu berlayar, dan rute mana yang diambil untuk sampai ke tempat tujuan.

Mengingat artikel ini adalah bentuk paparan studi literatur, maka penelitian ini belum memberikan gambaran nyata tentang apa yang terjadi di lapangan, atau di dalam konteks Indonesia secara spesifik. Namun demikian, studi ini dapat memberikan dasar atau pengetahuan awal bagi peneliti-peneliti selanjutnya untuk melakukan penelitian terapan terkait dengan strategi untuk mengatasi kecemasan berbicara dalam pembelajaran ESL/EFL.

\section{Daftar Pustaka}

Bailey, P., Onwuegbuzie, A.J., \& Daley, C.E. (2000). Correlates of Anxiety at Three Stages of the Foreign Language Learning Process [Electronic version]. Journal of Language and Social Psychology, 19, 474-490.

Chen, T. Y., \& Chang, G. B. (2004). The Relationship between Foreign Language Anxiety and Learning Difficulties. Foreign Language Annals, 37(2), 278-289.

Daubney, M. (n.d.). Language Anxiety: Creative or Negative Force in the Language Classroom? Retrieved October 15, 2007, from http://www.appi.pt/recursos/docsf ormacao/MDaubney1.pdf 
Dornyei, Z. (2001). Motivational Strategies in the Language Classroom. Cambridge: Cambridge University Press.

Ewald, J. D. (2007). Foreign language learning anxiety in upper-level classes: involving students as researchers [Electronic version]. Foreign Language Annals, 40(1), 122142.

Ganschow, L. \& Sparks, R. L. (2007). Is the Foreign Language Classroom Anxiety Scale Measuring Anxiety or Language Skills? [Electronic version]. Foreign Language Annals, 40(2), 260-286.

Gregersen, T., \& Horwitz, E. K. (2002). Language Learning and Perfectionism: Anxious and Nonanxious Language Learners' Reactions to Their Own Oral Performance [Electronic version]. The Modern Language Journal, 86(4), 562-570.

Horwitz, M.B., Horwitz, E.K., \& Cope, J.A. (1986). Foreign Language
Classroom Anxiety. The Modern Language Journal, 70(2), 125-132.

Kondo, D. S., \& Ling, Y. Y. (2004). Strategies for Coping with Language Anxiety: The Case of Students of English in Japan. ELT Journal, 58(3), 258-265.

Maclntyre, P. D. (1995). How Does Anxiety Affect Second Language Learning? A Reply to Sparks and Ganschow [Electronic version]. The Modern Language Journal, 79(1), 9099.

Nunan, D. (1999). Second Language Teaching \& Learning. Boston: Heinle \& Heinle Publishers.

Pappamihiel, N.E. (2002). English as a Second Language Students and English Language Anxiety. Issues in the mainstream classroom. Proquest Education Journal, 36(3), 327-355.

Woodrow, L. (2006). Anxiety and Speaking English as a Second Language [Electronic version]. RELC Journal, 37 (3), 308-328. 